\title{
HVA SOM VIL SKJE
}

\section{Du vil bli \\ vasket}

hvit. Det du elsker

vil bli

stående

igjen. Gule strå i vinden

hvis

du elsket

gule strå på knausen

opp

mot

et himmelblått rom.

Jan Erik Vold 